\title{
CCR5 knockout suppresses experimental autoimmune encephalomyelitis in C57BL/ 6 mice
}

\author{
Sun Mi Gu, ${ }^{1, *}$, Mi Hee Park ${ }^{1, *}$, Hyung Mun Yun ${ }^{2}$, Sang Bae Han ${ }^{1}$, Ki Wan Oh ${ }^{1}$, Dong \\ Ju Son ${ }^{1}$, Jae Suk Yun ${ }^{3}$ and Jin Tae Hong ${ }^{1}$ \\ ${ }^{1}$ College of Pharmacy and Medical Research Center, Chungbuk National University, Osongsaengmyeong 1-ro, Osong-eup, \\ Heungdeok-gu, Cheongju-si, Chungcheongbuk-do, Republic of Korea \\ 2 Department of Maxillofacial Tissue Regeneration, School of Dentistry and Research Center for Tooth and Periodontal \\ Regeneration (MRC), Kyung Hee University, Kyungheedae-ro, Dongdaemun-gu, Seoul, Republic of Korea \\ ${ }^{3}$ Pharmacological Research Division, National Institute of Food and Drug Safety Evaluation (NIFDS), Ministry of Food and \\ Drug Safety (MFDS), Osongsaengmyeong 2-ro, Osong-eup, Heungdeok-gu, Cheongju-si, Chungcheongbuk-do, Republic of \\ Korea \\ * These authors have contributed equally to this work
}

Correspondence to: Jae Suk Yun, email: actpotyjs@korea.kr

Jin Tae Hong, email: jinthong@chungbuk.ac.kr

Keywords: multiple sclerosis; C-C chemokine receptor 5; cytokine; chemokine; experimental autoimmune encephalomyelitis; Immunology and Microbiology Section; Immune response; Immunity

Received: August 30, $2015 \quad$ Accepted: February 28, 2016

Published: March 15, 2016

\section{ABSTRACT}

Multiple sclerosis (MS) is an inflammatory disease in which myelin in the spinal cord is damaged. C-C chemokine receptor type 5 (CCR5) is implicated in immune cell migration and cytokine release in central nervous system (CNS). We investigated whether CCR5 plays a role in MS progression using a murine model, experimental autoimmune encephalomyelitis (EAE), in CCR5 deficient (CCR5 ${ }^{-/-}$) mice. CCR5 ${ }^{-/-}$and $\mathrm{CCR5}^{+/+}$(wild-type) mice were immunized with myelin oligodendrocyte glycoprotein 35-55 (MOG 35-55 ) followed by pertussis toxin, after which EAE paralysis was scored for 28 days. We found that clinical scoring and EAE neuropathology were lower in $\mathrm{CCR5}^{-/-}$mice than $\mathrm{CCR5}^{+/+}$mice. Immune cells $\left(\mathrm{CD3}^{+}, \mathrm{CD4}^{+}, \mathrm{CD}^{+}, \mathrm{B}\right.$ cell, $\mathrm{NK}$ cell and macrophages) infiltration and astrocytes/microglial activation were attenuated in $\mathrm{CCR5}^{-/-}$mice. Moreover, levels of IL-1 $\beta$, TNF- $a$, IFN-Y and MCP-1 cytokine levels were decreased in $\mathrm{CCR}^{-/-}$mice spinal cord. Myelin basic protein (MBP) and CNPase were increased while NG2 and 04 were decreased in $\mathrm{CCR5}^{-/-}$mice, indicating that demyelination was suppressed by CCR5 gene deletion. These findings suggest that CCR5 is likely participating in demyelination in the spinal cord the MS development, and that it could serve as an effective therapeutic target for the treatment of MS.

\section{INTRODUCTION}

The autoimmune response in the central nervous system (CNS) plays a critical role in chronic inflammation and demyelination in human multiple sclerosis (MS) and in the animal model, experimental autoimmune encephalomyelitis (EAE) [1]. EAE is widely used as and animal model of human CNS demyelinating diseases, including MS [2]. It is mediated by activated myelin antigen-specific $\mathrm{CD}^{+}$Th1 cells and is characterized histologically by $\mathrm{Ag}$-specific and nonspecific $\mathrm{CD} 4^{+}$ and $\mathrm{CD}^{+}$Th1 cell infiltration [3]. Oligodendrocyte damage and apoptosis in response to CNS autoimmune inflammation are widely considered to be the pathological bases of MS and EAE, and are believed to result from the release of pro-inflammatory mediators and nitric oxide (NO) by activated T cells, macrophages, B cells, NK cells and activated glial cells [4].

In patients, each subsequent EAE episode following initial disease onset has been correlated with increased expression of inflammatory cytokines, such as TNF- $\alpha$ and IFN- $\gamma[5,6]$. Initial reports claimed that in vivo TNF blockade in mice and rats resulted in EAE amelioration [7, 8]. Further studies using TNF-deficient mice identified TNF as critical pathogenic cytokine that induces chemokine expression in the CNS $[9,10]$. IFN- $\gamma$ 
aggravates the course of neuroinflammatory disorders through microglia activation [11]. Interleukin-1 (IL-1) is produced by a variety of cells, such as monocytes/ macrophages, epithelial and endothelial cells and glial cells [12]. These cytokine plays a crucial role in leukocyte extravasation into inflammatory sites through upregulation of intracellular adhesion molecule-1 and vascular cell adhesion molecule-1 [13]. Monocyte chemotactic protein $1(\mathrm{MCP}-1)$ is unregulated $\mathrm{T}_{\mathrm{h}} 1$ immune responses during the acute phase of disease induced by myelin oligodendrocyte glycoprotein 35-55 $\left(\mathrm{MOG}_{35-55}\right)$ or other encephalitogenic antigens [14-16]. Vaccination with naked MCP-1 DNA inhibited EAE in mice [17]. Our previous study also found that MCP-1 levels were significantly reduced in lung tumor tissue and blood in CCR5-deficient mice compared with controls [18].

Chemokines interact with their respective cell surface receptors and mediate the recruitment of specific leukocyte subpopulations to sites of inflammation. Disruption of C-C chemokine receptors (CCR) may lead to impaired monocyte function, including chemokinedirected chemotaxis, and CCR manipulation may aid in inflammatory disease resistance $[19,20]$. C-C chemokine receptor 5 (CCR5) is implicated in immune cell migration and cytokine release in the CNS, and may play a role in the pathogenesis of MS and EAE. CXCL12 is associated infiltrating leukocytes, CXCR7 antagonist inhibited function of CXCL12, so CXCR7, a CXCL12 receptor), impacted both MS severity and recovery during EAE [21], however, CXCR6 is required for T cell infiltration into spinal cord following cortical injury [22]. In vivo studies indicated the MCP-1 and CCR2 might promote EAE initiation and progression. In addition, CCR1, 3 and 5 antagonist prevented demyelination syndromes [23]. EAE-mediated central nerve damage was ameliorated in IL-9 deficient mice via decreased CCR2, CCR5 and CCR6 expression [24].

Immunologic processes contribute to the initiation and continuation of MS and EAE, and recent studies have indicated that microglia, astrocytes and infiltrating immune cells have separate roles in MS lesion development [25]. The role of cytokines as important regulatory elements in these immune processes has been well established in EAE and the presence of cytokines in cells at the edges of MS lesions has been observed [26]. To assess the importance of CCR5 signaling in EAE pathogenesis, we induced disease in $\mathrm{CCR}^{-/}$and $\mathrm{CCR}^{+/+}$animals using the encephalitogenic peptide, $\mathrm{MOG}_{35-55}$. Mice lacking CCR5 were resistant to EAE, failed to develop mononuclear cell infiltrates, and displayed decreased pro-inflammatory responses in the CNS and spinal cord.
A

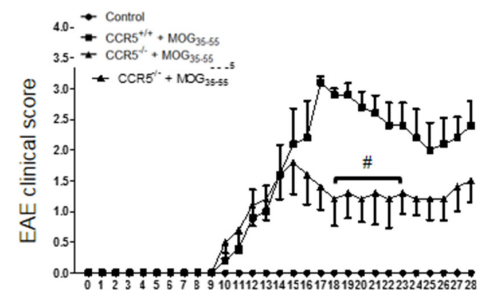

Day after immunization

C

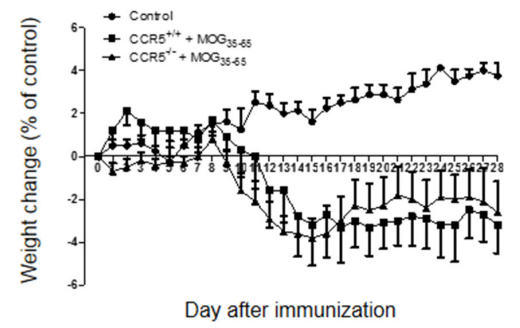

B

\begin{tabular}{lcc}
\hline & $\begin{array}{c}\text { Maximal mean } \\
\text { score } \pm \mathrm{SD}\end{array}$ & $\begin{array}{c}\text { Mean day of } \\
\text { onset } \pm \mathrm{SD}\end{array}$ \\
\hline Control & - & - \\
$\mathrm{CCR}^{+/+}+\mathrm{MOG}_{35-55}$ & $3.1 \pm 0.2$ & $11.8 \pm 1.8$ \\
$\mathrm{CCR}^{-/+}+\mathrm{MOG}_{35-55}$ & $1.8 \pm 1.2^{\#}$ & $11.2 \pm 1.8$ \\
\hline
\end{tabular}

D

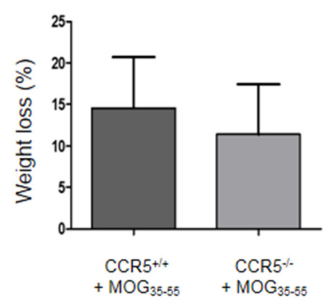

Figure 1: MOG $_{35-55}$-induced EAE in $\mathrm{CCR5}^{+/+}$and $\mathrm{CCR5}^{+/+}$mice. Mean clinical scores of age- and sex-matched control mice after saline and $\mathrm{CCR}^{+++}$and $\mathrm{CCR}^{-/-}$mice after induction of EAE with $\mathrm{MOG}_{35-55}$ A. Control mice group had no symptoms B. Maximal mean score was $1.8 \pm 0.2$ in $\mathrm{MOG}_{35-55}$-immunized $\mathrm{CCR}^{-/-}$mice and 3.1 \pm 1.2 in $\mathrm{MOG}_{35-55}$-immunized $\mathrm{CCR}^{+/+}$mice. Mean day of onset was the same for CCR5 ${ }^{+/+}(11.8 \pm 1.8)$ and $\mathrm{CCR} 5^{-/}(11.2 \pm 1.8)$ mice. Mean body weight $(\mathrm{g})$ was compared to day 0 in each group after injection of saline or $\mathrm{MOG}_{35-55}$ for 28 days $\mathbf{C}$. At day 28, control mouse body weight had increased 3.8 $\pm 2.2 \mathrm{~g}$, but had decreased $3.2 \pm 3.2 \mathrm{~g}$ and $2.6 \pm 3.0$ $\mathrm{g}$ in MOG35-55-immunized CCR5 ${ }^{+/+}$and CCR5 $5^{-/}$mice, respectively. Weight loss (\%) was not different between $\mathrm{MOG}_{35-55^{-}}$induced $^{-1} \mathrm{CR}^{+/+}$

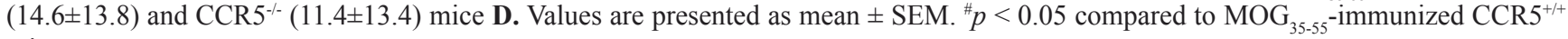
mice. 


\section{RESULTS}

\section{CCR5 deficiency suppressed MOG $_{35-55}$-induced EAE}

$\mathrm{CCR}^{+/+}$and $\mathrm{CCR} 5^{-/}$mice sensitized at 8 weeks of age developed clinical signs of $\mathrm{MOG}_{35-55}$ peptide-induced EAE. Paralysis first appeared at day 9 in both groups. $\mathrm{CCR}^{-/-}$mice exhibited symptoms faster $\mathrm{CCR}^{+/+}$mice at the initiatory stage of paralysis, but mean clinical score was lower for the CCR $5^{-/}$group (Figure 1A \& 1B). Mean body weight changes were similar between $\mathrm{CCR} 5^{+/+}$and CCR5 ${ }^{-/}$mice (Figure 1C and 1D).

\section{Spinal cord injuries were decreased in $\mathrm{CCR5}^{-/-}$ mice}

Hematoxylin and Eosin (H\&E) staining in spinal cord sections showed that mononuclear cell infiltration into the injured area decreased in $\mathrm{CCR} 5^{-/}$as compared to $\mathrm{CCR}^{+/+}$mice (Figure 2A). Similarly, CCR $5^{-/-}$mouse spinal cord sections showed less reduction in Luxol Fast
Blue (LFB) staining as compared to those of $\mathrm{CCR}^{+/+}$ mice, indicating that less demyelination occurred in $\mathrm{CCR}^{-/-}$mouse spinal cords (Figure 2B).

\section{Inflammatory cytokine levels were decreased in $\mathrm{CCR5}^{-/}$mice}

We measured cytokine levels related to EAE via ELISA using spinal cord tissue from control, $\mathrm{CCR} 5^{+/+}$ and $\mathrm{CCR}^{-/-}$mice. Levels of inflammatory cytokines such as TNF- $\alpha$ and IFN- $\gamma$ were increased overall in both $\mathrm{CCR}^{+/+}$and $\mathrm{CCR}^{-/-}$mice, but were higher in CCR5+/+ mice (Figure 3A \& 3B). IL-1 $\beta$ and MCP-1 levels were also was increased in CCR5+/+ mice (Figure $3 \mathrm{C} \& 3 \mathrm{D}$ ). IL-1 $\beta$ contributes to the activation of auto-antigen-specific immune cells, and MCP-1 was upregulated in the CNS of acute EAE cases.

\section{Immune cell infiltration was decreased in CCR5 ${ }^{1-}$ mice}

We detected $\mathrm{CD}^{+}$(a T cell marker), $\mathrm{CD}^{+}$(a helper $\mathrm{T}$ cell marker), $\mathrm{CD}^{\mathrm{b}} \mathrm{b}^{+}$(a cytotoxic $\mathrm{T}$ cell marker), $\mathrm{CD} 11 \mathrm{~b}^{+}$

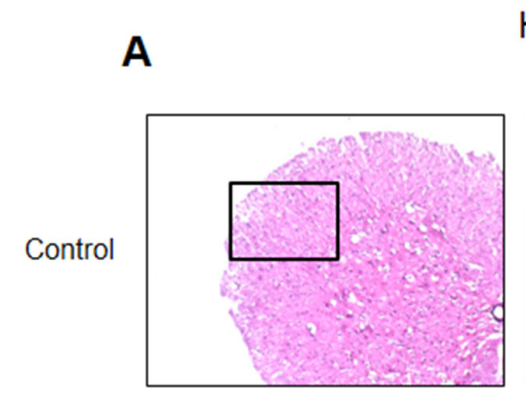

$H \& E$
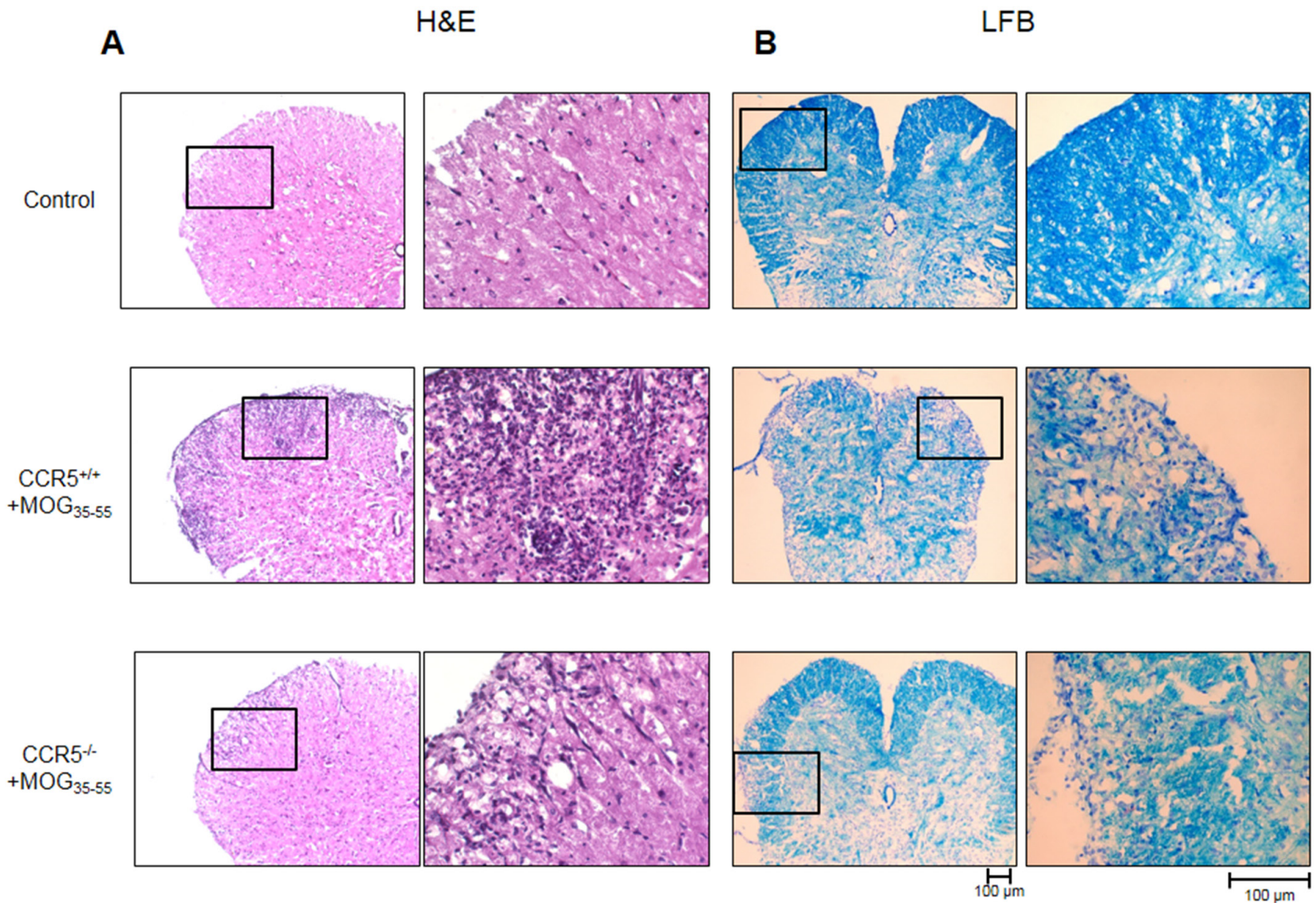

Figure 2: H\&E (cell infiltration) and LFB (demyelination) staining was performed in $16 \mu \mathrm{m}$-thick mouse spinal cord sections. Cell infiltration A. and demyelination B. was greater in $\mathrm{MOG}_{35-55}$-immunized CCR5 $5^{+/+}$mice than in $\mathrm{MOG}_{35-55}$-immunized CCR5${ }^{1}$ mice. 


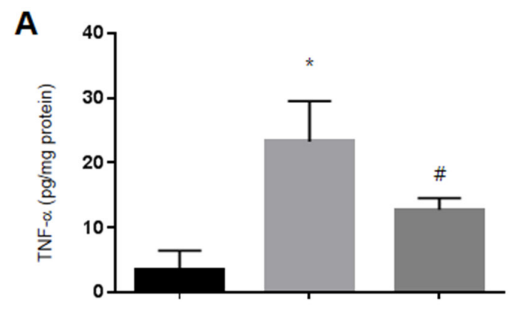

C

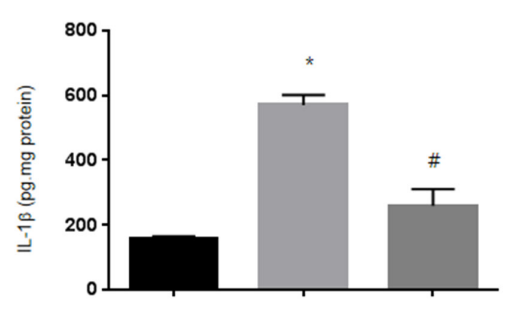

B

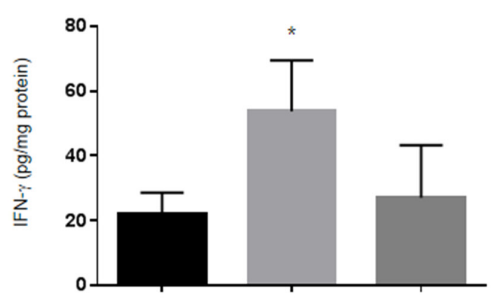

D

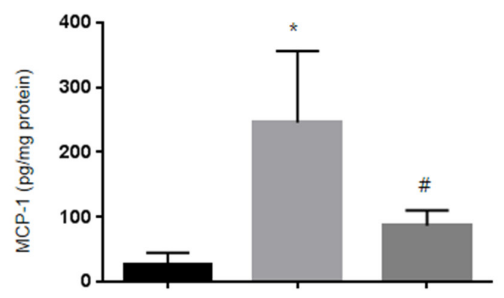

Figure 3: Levels of pro-inflammatory cytokines (TNF- $\alpha$, IFN- $\gamma$ and IL-1ß) and chemokines (MCP-1) in mouse spinal

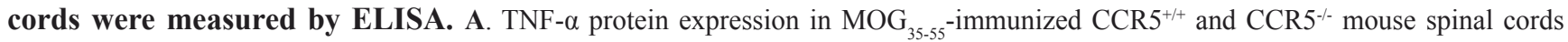
B. IFN- $\gamma$ expression was not significantly different between $\mathrm{MOG}_{35-55}$-immunized CCR5 $5^{+/+}$and CCR $5^{-/}$mouse spinal cords $\mathbf{C}$. $\mathrm{MOG}_{35-55}$ injection increased IL-1 $\beta$ expression in $\mathrm{CCR}^{+/+}$mice compared to CCR5 $5^{-/}$mice $\mathbf{D}$. MCP-1 expression in $\mathrm{MOG}_{35-55}$-immunized CCR5 $5^{++}$ mice was higher than in CCE 5 - mice. Values are presented as mean \pm SEM. ${ }^{*} p<0.05$ compared to control, ${ }^{\prime} p<0.05$ compared to $\mathrm{MOG}_{35}$.

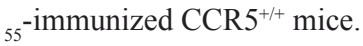

A
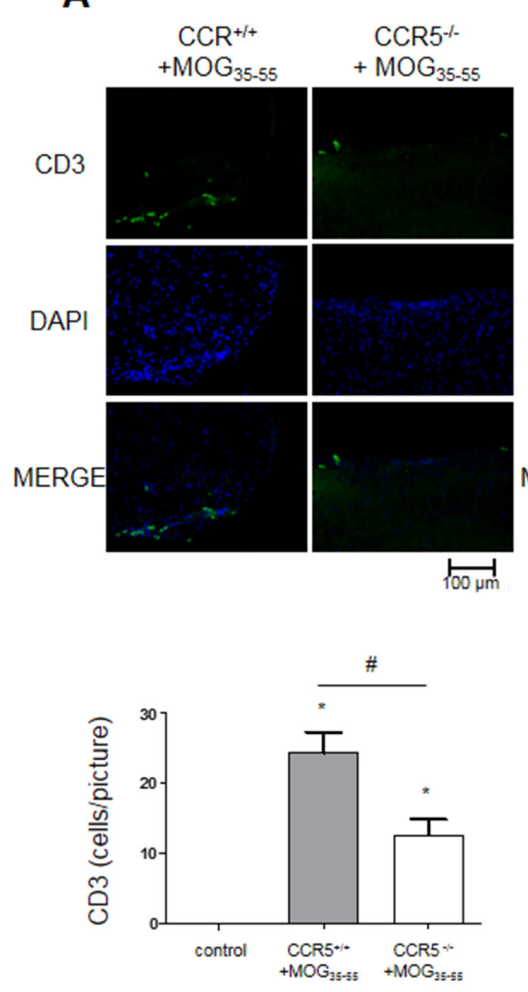

B
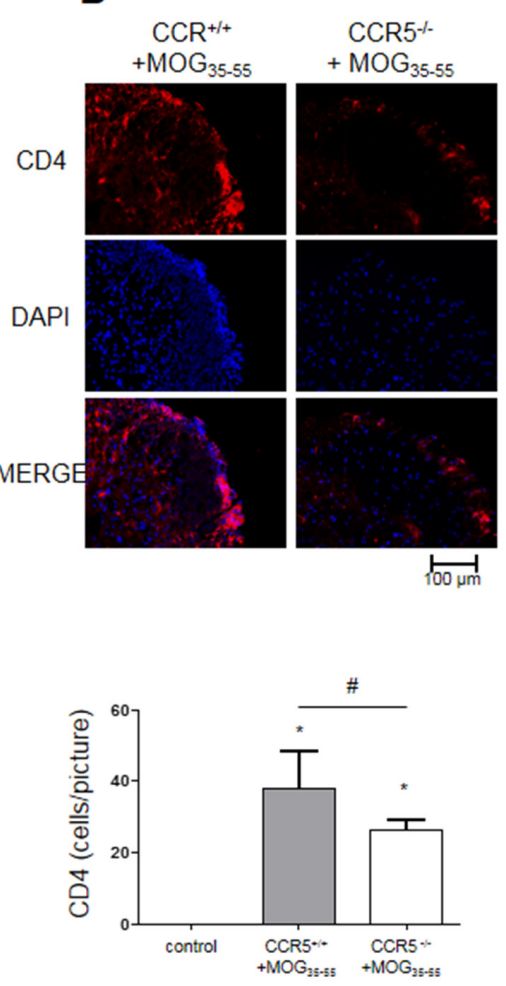

C
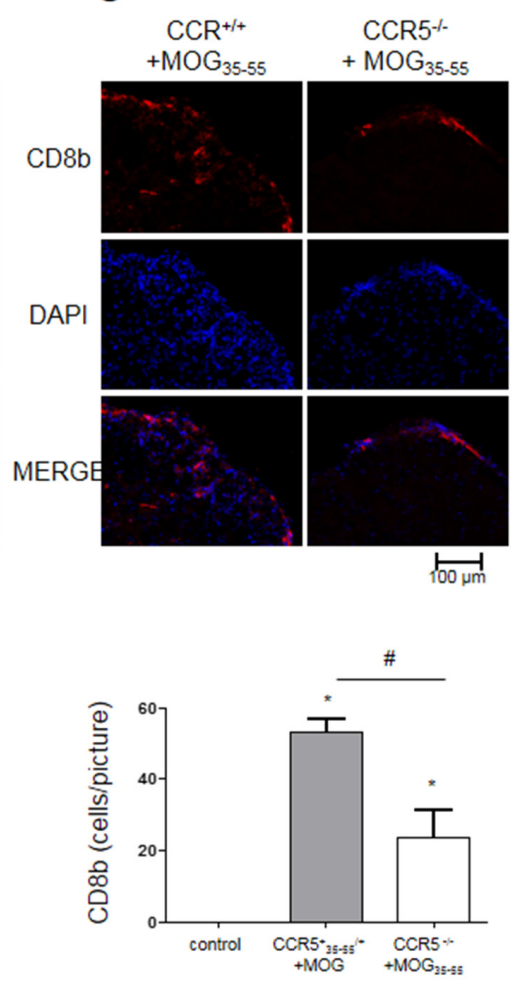

Figure 4: $\mathbf{T}$ cell infiltration as shown by IF staining in $\mathbf{1 6} \boldsymbol{\mu m}$-thick mouse spinal cord sections. $\mathrm{CD} 3^{+}, \mathrm{CD} 4^{+}, \mathrm{CD} 8^{+} \mathrm{T}$ cells did not infiltrate control mouse spinal cord tissue. $\mathrm{MOG}_{35-55}$-induced mouse spinal cord tissues showed infiltrating $\mathrm{CD} 3^{+}, \mathrm{CD}^{+}, \mathrm{CD}^{+}$ T cells A.-C. Values are presented as mean \pm SEM. $(n=3){ }^{*} p<0.05$ compared to control, ${ }^{*} p<0.05$ compared to $\mathrm{MOG}_{35-55}$-immunized $\mathrm{CCR}^{+/+}$mice. 
(a macrophage and microglial cell marker), $\mathrm{F} 4 / 80^{+}$(a macrophage marker), CD16+ (an NK cell marker) and $\mathrm{CD}^{+} 9^{+}$(a B cell marker) via immunofluorescence (IF) staining of the spinal cord sections. We observed increased numbers of immune cells ( $\mathrm{T}$ cells, helper T cells, cytotoxic T cells, macrophages, NK cells and B cells) in the spinal cords of $\mathrm{CCR}^{+/+}$mice (Figure 4A \& S1). These results may explain why $\mathrm{CCR} 5^{+/+}$mice had higher clinical scores than $\mathrm{CCR}^{-/-}$mice.

\section{Increased myelin protein and decreased} oligodendrocytes progenitor cell marker levels in $\mathrm{CCR5}^{-/}$mice

We used IF staining to detect expression of CNPase (myelinating oligodendrocytes marker), myelin basic protein (MBP), NG2 (a marker of oligodendrocyte progenitor cells; OPCs), O4 (an oligodendrocyte marker), GFAP (a marker of astrocyte activation) and IBA-1 (a marker of microglia cell activation). CNPase and MBP were increased in $\mathrm{CCR}^{+/+}$mice, while $\mathrm{NG} 2$ and $\mathrm{O} 4$ were decreased in $\mathrm{CCR}^{-/-}$mice (Figure 5, S2A \& S2B). GFAP and IBA-1 were decreased in $\mathrm{CCR} 5^{-/}$mice as compared to $\mathrm{CCR}^{+/+}$mice (Figure S2C \& S2D).
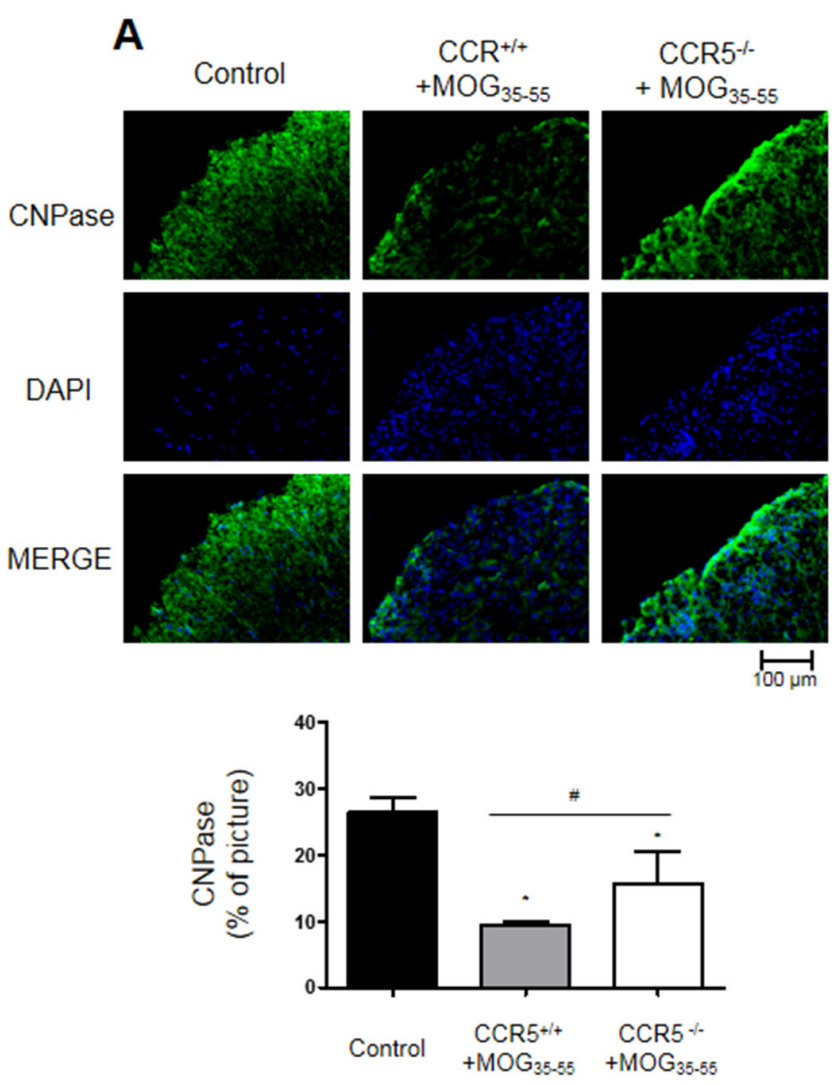

Decrease $T$ cell proliferation and inflammatory cytokine levels in Jurkat cells treated with con A and DAPTA

We stimulated Jurkat cells using con A (4 $\mu \mathrm{g} /$ $\mathrm{mL}$ ) and used a CCR5 antagonist (DAPTA, $10 \mu \mathrm{M}$ ) to suppress CCR5 activity. Cell viability, as measured by MTT assay, was increased by con A treatment and this effect was attenuated by DAPTA treatment (Figure 6A). Cell proliferation, as measured by BrdU assay, showed the same results as cell viability tests (Figure 6B). Jurkat cells were then stimulated under the same treatment conditions and inflammatory cytokine levels were measured using real-time PCR. TNF- $\alpha$ and IFN- $\gamma$ mRNA levels were increased in con A-treated Jurkat cells, but decreased in cells treated with DAPTA and con A together. IL-1 $\beta$ and MCP-1 mRNAs were rarely detected in all groups (Figure $6 \mathrm{C}-6 \mathrm{~F})$.

\section{DISCUSSION}

Chemokine receptors (CCRs) are involved in the pathogenesis of EAE and autoimmune disease [27]. $\mathrm{CCR}^{-/}, \mathrm{CCR}^{-/-}, \mathrm{CCR}^{-/-}$and $\mathrm{CXCR} 2^{-/-}$mice exhibited
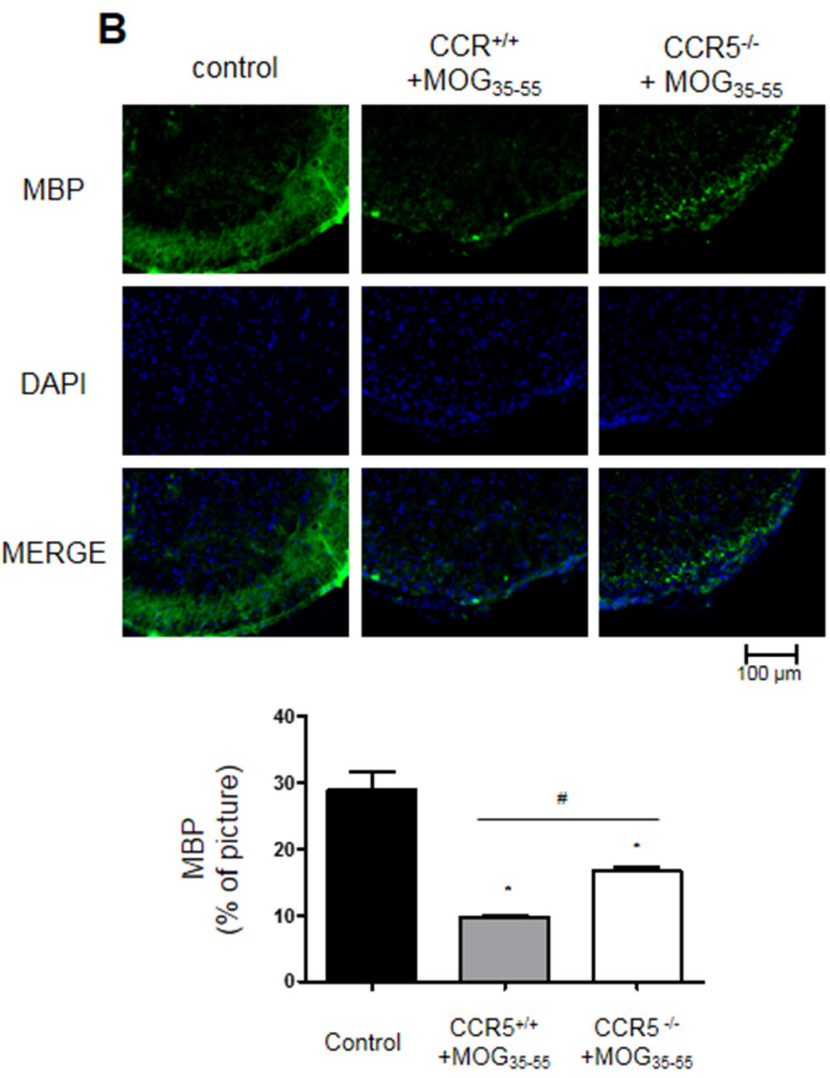

Figure 5: Myelin protein expression as shown by IF staining in $16 \boldsymbol{\mu m}$-thick mouse spinal cord sections. CNPase (myelinating oligodendrocyte marker) A. and NG2 (oligodendrocyte precursor maker) B. expression decreased in $\mathrm{MOG}_{35-55}$-induced $^{-{ }^{2}}$ $\mathrm{CCR} 5^{+/+}$mouse spinal cords as compared to $\mathrm{CCR} 5^{-/-}$mice spinal cord. Values are presented as mean \pm SEM. $(n=3)^{*} p<0.05$ compared to control, ${ }^{*} p<0.05$ compared to $\mathrm{MOG}_{35-55}$-immunized $\mathrm{CCR} 5^{+/+}$mice. 
reduced EAE symptoms compared to controls [9, 28-30]. $\mathrm{CCR}^{-/-}$mice did not develop EAE [31]. CXCR3 blockade inhibited leukocyte infiltration in the CNS [32]. CCR6 ${ }^{-1-}$ mice showed delayed EAE onset and the course of disease was more severe in $\mathrm{CCR}^{+/+}$mice [33]. However critical mechanisms and roles of CCR5 in EAE pathogenesis are not clear yet.

CCR5 is associated with some ligands, such as CCL3 CCL4 and CCL5 [34], that participant in the inflammatory response [35]. Increase CCL5 levels has been reported in rheumatoid arthritis (RA), and positive patient responses to methotrexate therapy have been associated with CCL5 reductions $[35,36]$. Infiltrating $\mathrm{T}$ cells around high endothelial venules in RA synovium, and approximately $85 \%$ of synovial fluid $\mathrm{CD}^{+} \mathrm{CD} 4^{+}$ $\mathrm{T}$ cells expressed CCR5 [37]. In active systemic lupus
A

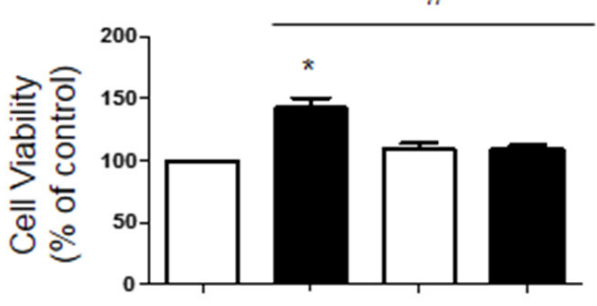

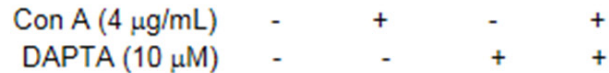

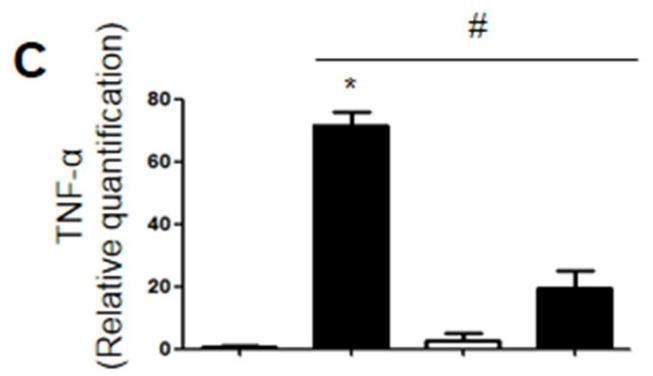

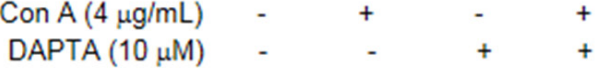

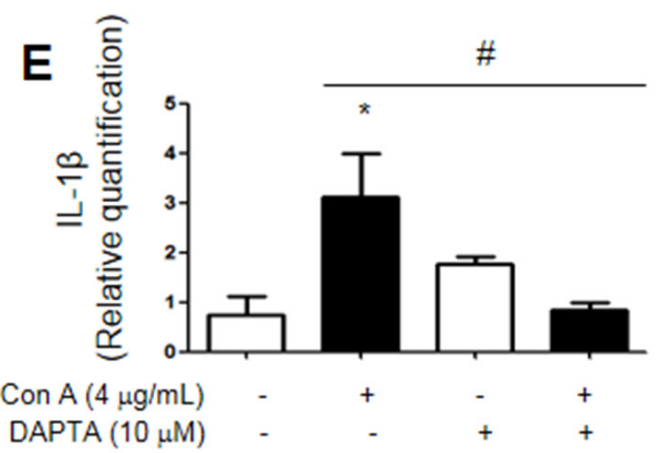

erythematous (SLE) patients, CCR5 levels on the surface of $\mathrm{CD}^{+} \mathrm{T}$ cells were higher compared with patients in remission and healthy controls [38].

While we observed significant differences between $\mathrm{CCR}^{+/+}$and CCR5 $5^{-/}$mice with MOG35-55induced EAE, Tran, et al. reported very few differences [39]. These differences may be due to the fact that they injected only half the amounts of both $\mathrm{MOG}_{35-55}$ peptide and Mycobacterium tuberculosis H37RA into mice as in the present study. Zheng et al. reported that inhibiting CCR5 led to reduced EAE onset and development [40]. Additionally, patients with MS exhibit a higher percentage of circulating $\mathrm{CCR}^{+}$cells than controls, and an increased number of these cells is associated with disease severity [41]. This and our results indicate that CCR5 may be significant in the development of EAE.

B
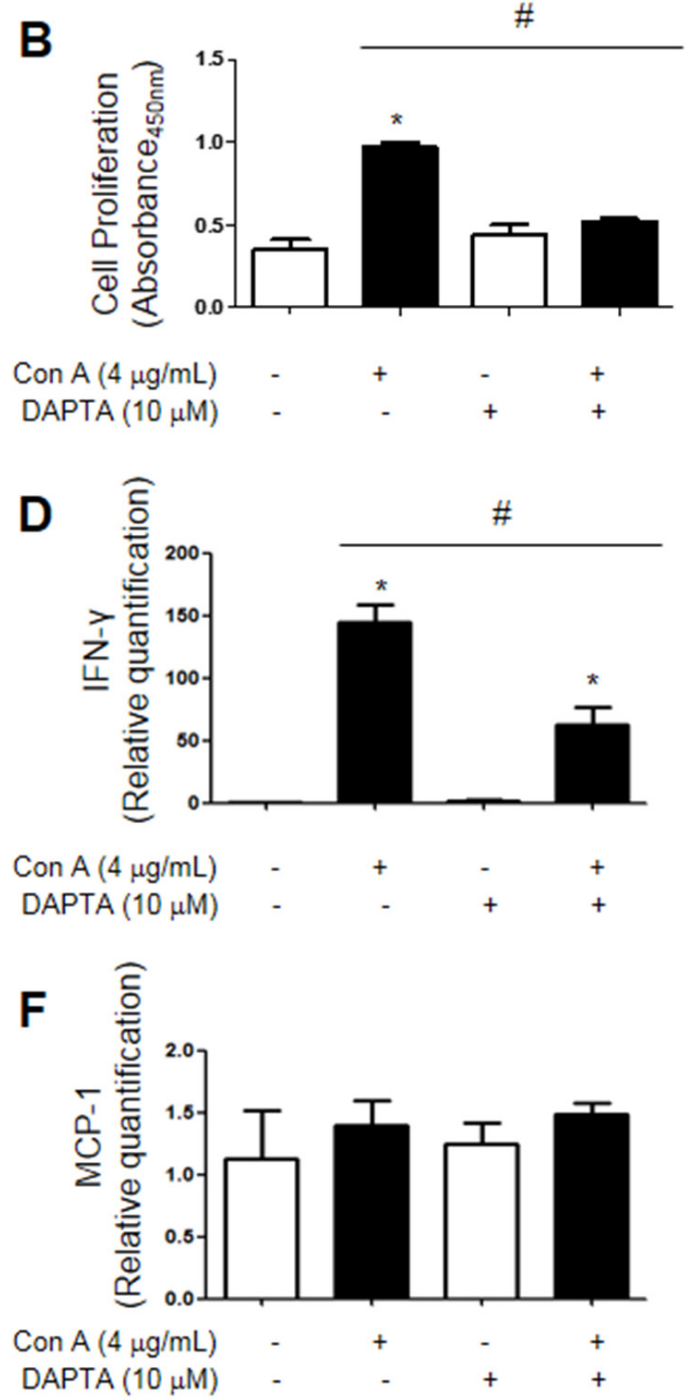

Figure 6: Jurkat cells were stimulated using con A $(4 \mu \mathrm{g} / \mathrm{mL})$ and CCR5 was inhibited using DAPTA (10 $\mu$ M). Con A treatment enhanced cell viability (MTT assay) A. and proliferation (BrdU assay) B. compared to controls, but this effect was reversed by DAPTA. As measured by real-time PCR, TNF- $\alpha$, IFN- $\gamma$, IL- $1 \beta$ and MCP-1 levels were increased in con A-treated cells, but were decreased in cells treated with both con A and DAPTA C.-F. Values are presented as mean \pm SEM. $(n=3)^{*} p<0.05$ compared to control, \#p<0.05 compared to con A-treated cells. 
Change of chemokine levels, including that of TNF- $\alpha$, IFN- $\gamma$, MCP-1 and IL-1, are correlated with the development of EAE. The direct action of TNF- $\alpha$ in the pathogenesis of EAE was confirmed by peripheral administration of a neutralizing anti-murine TNF- $\alpha$ antibody. This treatment completely prevented T-cell infiltration into the CNS and demyelination [42]. Peripheral blood $\mathrm{CCR}^{+} \mathrm{T}$ cells secreted high levels of IFN- $\gamma$, and IFN- $\gamma$ was observed in demyelinating lesions [43]. IL-1 receptor antagonists successfully prevented or suppressed EAE [44, 45]. Similarly, IL-1 receptor gene deficient mice are resistant to EAE [46]. Our data showed that TNF- $\alpha$, IFN- $\gamma$ and IL- $1 \beta$ levels in $\mathrm{CCR}^{-/-}$mice were much higher than in controls, but were lower than in $\mathrm{CCR}^{+/+}$mice.

MCP-1 is a member of the $\mathrm{C}-\mathrm{C}$ chemokine family and regulates the migration and infiltration of monocytes, dendritic cells, T cells and NK cells [47]. MCP-1 levels in the CNS are dramatically increased during the relapsing phase of chronic relapsing EAE, and MCP-1 antibodies can effectively mitigate disease severity [48-50]. MCP1/- mice are also resistant to EAE and exhibit reduced CNS macrophages, neutrophille and $\mathrm{T}$ cells infiltration [16, 51]. In our experiments, MCP-1 was decreased in CCR5 ${ }^{1}$ mice compared to $\mathrm{CCR}^{+/+}$mice. These data suggest that reduced levels of pro-inflammatory cytokines, especially IL-1 and MCP-1, could inhibit EAE development.

In MS and the EAE mice model, morphologically indistinguishable phagocytic cells accrue as a result of proliferation of resident precursors and recruitment of blood-borne progenitors, respectively [52]. Our data showed that infiltration of $\mathrm{CD} 11 \mathrm{~b}^{+}$(monocyte), F4/80 (macrophage), CD16 ${ }^{+}$(NK cell) and $\mathrm{CD}^{+} 9^{+}$(B cell) cells infiltration was decreased in $\mathrm{CCR}^{-/}$mice spinal cord tissue compared to $\mathrm{CCR}^{+/+}$mice tissue. Previous studies regarding MS immunopathology have shown that autoreactive pro-inflammatory $\mathrm{T}$ cells play an important role in the propagation of CNS tissue injury. Interaction between APCs, such as macrophages and dendritic cells, and $\mathrm{T}$ cells lead to cytokine-mediated $\mathrm{T}$ cell activation and proliferation [53]. T cell-mediated immune response to various myelin antigens is a major cause of demyelination [54]. EAE is induced by immunization with myelin, myelin proteins, and myelin protein encephalitogenic epitopes, or by the passive transfer of myelin-reactive CD4 T cells $[55,56]$. CD4 $\mathrm{T}$ cells differentiate further into $\mathrm{T}_{\mathrm{h}} 1$ cells which synthesize inflammatory cytokines, such as TNF- $\alpha$ and IFN- $\gamma[57,58]$. Histological analysis of acute MS cases showed CD8 T cells in close proximity or attached to oligodendrocytes or demyelinated axons. Studies have also demonstrated the presence and activation of myelinreactive and $\mathrm{CD}^{+} \mathrm{T}$ cells in the blood and cerebrospinal fluid (CSF) of MS patients [59-61]. Our data showed that $\mathrm{CD}^{+}, \mathrm{CD}^{+}$and $\mathrm{CD}^{+} \mathrm{T}$ cell infiltration decreased in $\mathrm{CCR}^{-/-}$mice spinal cords as compared to $\mathrm{CCR} 5^{+/+}$mice. Our data support the findings of Simpson, Sørensen et al., who detected CCR5 on lymphocytic cells, macrophages and microglial cells in actively demyelinating MS lesions $[62,63]$.

Other studies have also linked CCRs or CXCRs to immune cell infiltration in injury. CCR2-dificient spinal cord sections showed fewer infiltrating $\mathrm{CD}^{+}$and $\mathrm{CD}^{+} \mathrm{T}$ cells and $\mathrm{F} 4 / 80^{+}$macrophages [29], and MHVinfected CCR5-/- mice had reduced levels of infiltrating $\mathrm{T}$ cells present during acute disease [64]. $\mathrm{CCR}^{-/-}$mice also reportedly showed poor migration of immune cells (including NK and T cells) [65, 66]. Mohan, et al. found that sections of joints from anti-CXCR3 mAbtreated animals exhibited a marked decrease in synovial leukocytes infiltration [67].

The Jurkat cell, a human mature leukemic cell line, phenotypically resembles resting human $\mathrm{T}$ lymphocytes and has been widely used to study T cell physiology [68]. We treated Jurkat cells with concanavalin A (ConA), an antigen-independent mitogen that induces $\mathrm{T}$ cells proliferation [69], and DAPTA, an antagonist of CCR5mediated chemotaxis [70]. Levels of cytokines, including TNF- $\alpha$ and IFN- $\gamma$, were induced by con A treatment and this effect was reversed by DAPTA, as measured by both cell viability and proliferation assays. However, IL-1 is strongly expressed by monocytes, tissue macrophages and dendritic cells $[71,72]$. MCP-1 is also produced by macrophages, fibroblasts, epithelial cells and endothelial cells [73], so IL-1 $\beta$ and MCP-1 was rarely detected in Jurkat cells. These cytokines and chemokines were produced in vivo in macrophages in spinal cord tissue, and secreted IL-1 $\beta$ and MCP-1 might impact T cells in ways not observed in our in vitro cultures [47]. We concluded that CCR5 gene knockout suppresses EAE and reduces demyelination via regulation of immune cells and several cytokines. CCR5 is likely participating in demyelination in the spinal cord of the MS development, and could be and effective therapeutic target for treatment of MS and other neuropathological disease.

\section{MATERIALS AND METHODS}

\section{Animals}

$\mathrm{CCR}^{-/-}$mice (B6.129P2-Ccr5 $5^{\text {tm } 1 \mathrm{Kuz} / \mathrm{J}}$ ), with full CCR5 gene coding region deletions, were obtained from The Jackson Laboratory (Bar Harbor, ME, USA). Agematched, 8-week old CCR5 ${ }^{+/+}$mice (B6129PF2/J) from the same supplier were used as wild-type controls. Animals were maintained in conventional housing at $23 \pm 2{ }^{\circ} \mathrm{C}$ with a controlled $12 \mathrm{~h}$ light/dark cycle, and drinking water and rodent chow were provided throughout the experiment. All experiments were approved and carried out according to the Guidelines for the Care and Use of Animals [Animal Care Committee of Chungbuk National University, Korea 


\section{Histological analysis}

\section{EAE induction}

$\mathrm{CCR}^{-/}$and $\mathrm{CCR}^{+/+}$mice were immunized with $\mathrm{MOG}_{35-55}$ peptide emulsified with complete Freund's adjuvant (CFA) using Hooke kits (Hooke laboratories, EK-0115, Lawrence, MA, USA) according to the manufacturer's instructions. In brief, 0.1 mL MOG35-55/ CFA emulsion was injected subcutaneously into the upper and lower back of each mouse $(0.2 \mathrm{~mL} /$ animal $)$ followed by intraperitoneal (i.p.) injections of $0.1 \mathrm{ml}$ pertussis toxin (PTX). Twenty-four hours later, booster shots of PTX (0.1 $\mathrm{ml} /$ animal, i.p.) were given. Normal saline-administrated $\mathrm{CCR}^{+/+}$mice were used as controls.

\section{Clinical evaluation of EAE}

A masked investigator examined and scored mice daily for clinical signs of neurological deficit according to the following scale: grade 0 , no abnormality; grade 0.5 , partial tail paralysis; grade 1 , complete tail paralysis; grade 1.5, complete tail paralysis and clumsy gait; grade 2 , complete tail paralysis and hind limb weakness; grade 2.5 , unilateral hind limb paralysis; grade 3 , complete hind limb paralysis; grade 3.5, complete hind limb paralysis and fore-limb weakness; grade 4, tetraplegia; grade 5, moribund state or death. Data were plotted as daily mean clinical score for all animals in a particular treatment group, including the scores of asymptomatic mice (score =0) [74-76].

\section{Jurkat cell culture}

Jurkat cells were maintained in Roswell Park Memorial Institute (RPMI) 1640 culture media supplemented with fetal bovine serum (FBS) $(10 \%)$ and penicillin $(100$ units $/ \mathrm{ml})$. Cells were maintained in a humidified incubator at $37^{\circ} \mathrm{C}$ and $5 \% \mathrm{CO}_{2}$, and were treated simultaneously with con A $(4 \mu \mathrm{g} / \mathrm{mL})$ and a CCR5 antagonist (D-Ala -peptide T-NH $_{2}$; DAPTA; Bachem Bioscience Inc., King of Prussia, PA) $(10 \mu \mathrm{M})$ dissolved in distilled water.

\section{Spinal cord collection and preservation}

After behavioral tests, mice were perfused with phosphate-buffered saline (PBS, pH 7.4) under inhaled diethyl ether anesthetization. Spinal cords were immediately pulled from the skull and cut. One removed spinal column was stored at $-80^{\circ} \mathrm{C}$; the remainder were fixed in $4 \%$ paraformaldehyde for $72 \mathrm{~h}$ at $4{ }^{\circ} \mathrm{C}$ and transferred to $30 \%$ sucrose solutions.
Spinal cords from 30\% sucrose solutions were cut into 16 ?ere cut intusing a cryostat microtome (Leica CM 1850; Leica Microsystems, Seoul, Korea) and stained with LFB/Crystal Violet (LFB, IHC World, Ellicott City, MD) and $\mathrm{H} \& \mathrm{E}$ for identification of intact myelin and infiltrating cells, respectively. Sections were evaluated via light microscopy (Olympus, Tokyo, Japan) $\left({ }^{X_{50} \text { or }} \times_{200}\right)$.

\section{Immunofluorescence staining}

After two 10-min washes in PBS (pH 7.4), endogenous peroxidase activity was quenched by incubating prepared spinal cord sections in 3\% hydrogen peroxide in PBS for $20 \mathrm{~min}$, followed by an additional two 10 -min washes in PBS. Sections were blocked for $1 \mathrm{~h}$ in $5 \%$ bovine serum albumin (BSA) and incubated overnight at $4{ }^{\circ} \mathrm{C}$ with a mouse polyclonal antibody against CNPase, MBP, NG2, O4 (1:200; Millipore, Billerica, MA, USA), CD3 or glial fibrillary acidic protein (GFAP) (1:200; Santa Cruz Biotechnology, Inc., Santa Cruz, CA, USA), a rat polyclonal antibody against F4/80 (1:100; Santa Cruz Biotechnology, Inc., Santa Cruz, CA, USA), CD4 (1:100, BD Biosciences, Franklin Lakes, NJ, USA), CD8b, CD11b or CD16/CD32 (1:100, eBioscince, San Diego, USA), or a goat polyclonal antibody against ionized calciumbinding adapter molecule 1 (IBA-1) (1:300; Abcam, Inc., Cambridge, MA, USA). Sections were then washed three times (10 min each) in PBS and incubated for 1-2 $\mathrm{h}$ at room temperature with a secondary antibody conjugated to Alexa Fluor 488 or 568 (Invitrogen-Molecular Probes, Carlsbad, CA, USA). Sections were then washed three times $(10 \mathrm{~min}$ each) in PBS, incubated for $30 \mathrm{sec}$ at room temperature in the dark for DAPI staining and mounted with Vecta mountTM AQ (Vecta Laboratories, Burlingame, CA). IF images were acquired using an inverted Zeiss Axiovert $200 \mathrm{M}$ fluorescent microscope (Carl Zeiss, Thornwood, NY, USA) (X100 or X200).

\section{Measurement of cytokines}

Protein was extracted from spinal cord tissues (lumbar regions) using protein extraction buffer (PROPREP $^{\mathrm{TM}}$, Intron Biotechnology, Korea) with protease inhibitors, incubated on ice for $2 \mathrm{~h}$ and centrifuged at $13,000 \mathrm{~g}$ for $15 \mathrm{~min}$ at $4^{\circ} \mathrm{C}$. TNF- $\alpha$, IFN- $\gamma$, IL- $1 \beta$ and MCP-1 levels were determined using ELISA Kits (R\&D Systems, Minneapolis, MN, USA). In brief, $100 \mu \mathrm{g} / \mu \mathrm{l}$ of sample was added into a precoated plate and incubated $2 \mathrm{~h}$ at RT. After washing each well of the precoated plate with a washing buffer, $100 \mu \mathrm{l}$ of labeled antibody solution was added, and the mixture was incubated for $2 \mathrm{~h}$ at RT. After washing, chromogen was added, and the mixture was 
incubated for $30 \mathrm{~min}$ at $\mathrm{RT}$ in the dark. The resulting color was assayed at $450 \mathrm{~nm}$ using a microplate absorbance reader (Sunrise ${ }^{\mathrm{TM}}$, Tecan, Switzerland) after adding stop solution within 30 minutes.

\section{Cell viability assay}

Jurkat cells were plated at a density of $1 \times 10^{4}$ cells/ well in 96-well plates in $200 \mu \mathrm{L}$ medium with DAPTA $(10 \mu \mathrm{M})$. After $2 \mathrm{hr}$, Jurkat cells were stimulated by con A $(4 \mu \mathrm{g} / \mathrm{mL})$ in $200 \mu \mathrm{L}$ medium for $12 \mathrm{~h}$. The cells were added to $30 \mu \mathrm{L}$ MTT [3-(4,5-dimethylthiazol-2yl)-2,5-diphenyl-tetrazoliumbromide] solution (final concentration of $5 \mathrm{mg} / \mathrm{mL}$ ) (Sigma, St. Louis, MO, USA). After $3 \mathrm{~h}$, MTT solution was removed, and the cells were added to dimethyl sulfoxide (DMSO) in $200 \mu \mathrm{L}$ for 30 min. Finally, the resulting color was assayed at $540 \mathrm{~nm}$ using a microplate absorbance reader (Sunrise ${ }^{\mathrm{TM}}$, Tecan, Switzerland).

\section{BrdU assay}

Jurkat cells were plated at $1 \times 10^{4}$ cells/well in 96well plates in $200 \mu \mathrm{L}$ medium with DAPTA $(10 \mu \mathrm{M})$. After $2 \mathrm{hr}$, Jurkat cells were stimulated by con A $(4 \mu \mathrm{g} / \mathrm{mL})$ in $200 \mu \mathrm{L}$ medium for $12 \mathrm{~h}$. Detection of BrdU incorporation was performed by ELISA (BrdU Cell Proliferation Assay Kit, Cell Signaling Technology, Danvers, MA, USA) according to the manufacturer's instructions.

\section{Quantitative real-time PCR (qPCR)}

For mRNA quantification, total RNA was extracted using the easy-BLUR ${ }^{\mathrm{TM}}$ total RNA extraction kit (iNtRON Biotech, Daejeon, Korea). cDNA was synthesized using High Capacity cDNA Reverse Transcription Kits (Applied Biosystems, Foster city, CA) according to the manufacturer's instructions. Briefly, $2 \mu \mathrm{g}$ of total RNA was used for cDNA preparation. Quantitative real-time PCR was performed using the Brilliatn III Ultra-Fast Green QPCR Master Mix (Agilent Technologies, Waldbronn, Germany) specific for $\beta$-actin (N1080, Bioneer, Daejeon, Korea), TNF- $\alpha$ (N-1072, Bioneer, Daejeon, Korea), IFN- $\gamma$ (N-1055, Bioneer, Daejeon, Korea), IL-1 $\beta$ (N-1058, Bioneer, Daejeon, Korea) and MCP-1 (5'-CCT TCA TTC CCC AAG GGC TC-3' and 5'-GGT TTG CTT GTC CAG GTG GT-3'). All reverse transcription reactions were run in a StepOnePlus Real-Time PCR System (Applied Biosystems, Foster city, CA) using the universal cycling parameters $\left(3 \min 95^{\circ} \mathrm{C}, 40\right.$ cycles of $5 \mathrm{~s} 95^{\circ} \mathrm{C}, 12 \mathrm{~s}$ $60^{\circ} \mathrm{C}$ ). Results were normalized to $\beta$-actin and quantified relative to expression in control samples. For relative quantification calculation, the $2^{-\Delta \Delta C \mathrm{~T}}$ formula was used, where:

$$
\begin{aligned}
& -\Delta \Delta \mathrm{CT}=\left(\mathrm{C}_{\mathrm{T} \text { target }}-\mathrm{C}_{\mathrm{T} \text {,beta-actin }}\right) \text { experimental sample - } \\
& \left(\mathrm{C}_{\mathrm{T} \text {,target }}-\mathrm{C}_{\mathrm{T} \text {,beta-actin }}\right) \text { control sample. }
\end{aligned}
$$

\section{Statistical analysis}

Statistical analysis were carried out using analysis of variance (ANOVA) for repeated measures followed by Dunnette's post-hoc analysis using GraphPad Prism 5 software (Version 5.01, GraphPad software, Inc., La Jolla, USA). Immune cell counts were determined using the ImageJ.

\section{CONFLICTS OF INTEREST}

The authors declare that they have no competing interests.

\section{GRANT SUPPORT}

This work was supported by the National Research Foundation of Korea (NRF) Grant funded by the Korea government (MSIP) (MRC, 2008-0062275).

\section{REFERENCES}

1. Pierson E, Simmons SB, Castelli L and Goverman JM. Mechanisms regulating regional localization of inflammation during CNS autoimmunity. Immunological reviews. 2012; 248:205-215.

2. Constantinescu CS, Farooqi N, O'Brien K and Gran B. Experimental autoimmune encephalomyelitis (EAE) as a model for multiple sclerosis (MS). British journal of pharmacology. 2011; 164:1079-1106.

3. Ellwardt E and Zipp F. Molecular mechanisms linking neuroinflammation and neurodegeneration in MS. Experimental neurology. 2014; 262 Pt A:8-17.

4. Merrill JE, Ignarro LJ, Sherman MP, Melinek J and Lane TE. Microglial cell cytotoxicity of oligodendrocytes is mediated through nitric oxide. Journal of immunology. 1993; 151:2132-2141.

5. Korner H, Goodsall AL, Lemckert FA, Scallon BJ, Ghrayeb J, Ford AL and Sedgwick JD. Unimpaired autoreactive T-cell traffic within the central nervous system during tumor necrosis factor receptor-mediated inhibition of experimental autoimmune encephalomyelitis. Proceedings of the National Academy of Sciences of the United States of America. 1995; 92:11066-11070.

6. Panitch HS, Hirsch RL, Schindler J and Johnson KP. Treatment of multiple sclerosis with gamma interferon: exacerbations associated with activation of the immune system. Neurology. 1987; 37:1097-1102.

7. Ruddle NH, Bergman CM, McGrath KM, Lingenheld EG, Grunnet ML, Padula SJ and Clark RB. An antibody to lymphotoxin and tumor necrosis factor prevents transfer 
of experimental allergic encephalomyelitis. The Journal of experimental medicine. 1990; 172:1193-1200.

8. Baker D, Butler D, Scallon BJ, O'Neill JK, Turk JL and Feldmann M. Control of established experimental allergic encephalomyelitis by inhibition of tumor necrosis factor (TNF) activity within the central nervous system using monoclonal antibodies and TNF receptor-immunoglobulin fusion proteins. European journal of immunology. 1994; 24:2040-2048.

9. Murphy CA, Hoek RM, Wiekowski MT, Lira SA and Sedgwick JD. Interactions between hemopoietically derived TNF and central nervous system-resident glial chemokines underlie initiation of autoimmune inflammation in the brain. Journal of immunology. 2002; 169:7054-7062.

10. Korner H, Riminton DS, Strickland DH, Lemckert FA, Pollard JD and Sedgwick JD. Critical points of tumor necrosis factor action in central nervous system autoimmune inflammation defined by gene targeting. The Journal of experimental medicine. 1997; 186:1585-1590.

11. Lee E, Chanamara S, Pleasure D and Soulika AM. IFNgamma signaling in the central nervous system controls the course of experimental autoimmune encephalomyelitis independently of the localization and composition of inflammatory foci. Journal of neuroinflammation. 2012; 9:7.

12. Matsuki T, Nakae S, Sudo K, Horai R and Iwakura Y. Abnormal $\mathrm{T}$ cell activation caused by the imbalance of the IL-1/IL-1R antagonist system is responsible for the development of experimental autoimmune encephalomyelitis. International immunology. 2006; 18:399-407.

13. Tamaru M, Tomura K, Sakamoto S, Tezuka K, Tamatani $\mathrm{T}$ and Narumi S. Interleukin-1beta induces tissue- and cell type-specific expression of adhesion molecules in vivo. Arteriosclerosis, thrombosis, and vascular biology. 1998; 18:1292-1303.

14. Kennedy KJ, Strieter RM, Kunkel SL, Lukacs NW and Karpus WJ. Acute and relapsing experimental autoimmune encephalomyelitis are regulated by differential expression of the CC chemokines macrophage inflammatory protein1alpha and monocyte chemotactic protein-1. Journal of neuroimmunology. 1998; 92(1-2):98-108.

15. Juedes AE, Hjelmstrom P, Bergman CM, Neild AL and Ruddle NH. Kinetics and cellular origin of cytokines in the central nervous system: insight into mechanisms of myelin oligodendrocyte glycoprotein-induced experimental autoimmune encephalomyelitis. Journal of immunology. 2000; 164:419-426.

16. Huang DR, Wang J, Kivisakk P, Rollins BJ and Ransohoff RM. Absence of monocyte chemoattractant protein 1 in mice leads to decreased local macrophage recruitment and antigen-specific $\mathrm{T}$ helper cell type 1 immune response in experimental autoimmune encephalomyelitis. The Journal of experimental medicine. 2001; 193:713-726.

17. Youssef S, Wildbaum G, Maor G, Lanir N, Gour-Lavie A, Grabie N and Karin N. Long-lasting protective immunity to experimental autoimmune encephalomyelitis following vaccination with naked DNA encoding C-C chemokines. Journal of immunology. 1998; 161:3870-3879.

18. Lee NJ, Choi DY, Song JK, Jung YY, Kim DH, Kim TM, Kim DJ, Kwon SM, Kim KB, Choi KE, Moon DC, Kim Y, Han SB and Hong JT. Deficiency of C-C chemokine receptor 5 suppresses tumor development via inactivation of NF-kappaB and inhibition of monocyte chemoattractant protein-1 in urethane-induced lung tumor model. Carcinogenesis. 2012; 33:2520-2528.

19. Boring L, Gosling J, Chensue SW, Kunkel SL, Farese RV, Jr., Broxmeyer HE and Charo IF. Impaired monocyte migration and reduced type 1 (Th1) cytokine responses in $\mathrm{C}-\mathrm{C}$ chemokine receptor 2 knockout mice. The Journal of clinical investigation. 1997; 100:2552-2561.

20. Kurihara T, Warr G, Loy J and Bravo R. Defects in macrophage recruitment and host defense in mice lacking the CCR2 chemokine receptor. The Journal of experimental medicine. 1997; 186:1757-1762.

21. Cruz-Orengo L, Chen YJ, Kim JH, Dorsey D, Song SK and Klein RS. CXCR7 antagonism prevents axonal injury during experimental autoimmune encephalomyelitis as revealed by in vivo axial diffusivity. Journal of neuroinflammation. 2011; 8:170.

22. Kim JV, Jiang N, Tadokoro CE, Liu L, Ransohoff RM, Lafaille JJ and Dustin ML. Two-photon laser scanning microscopy imaging of intact spinal cord and cerebral cortex reveals requirement for CXCR6 and neuroinflammation in immune cell infiltration of cortical injury sites. Journal of immunological methods. 2010; 352(1-2):89-100.

23. Di Prisco S, Merega E and Pittaluga A. Functional adaptation of presynaptic chemokine receptors in EAE mouse central nervous system. Synapse. 2014; 68:529-535.

24. Li H, Nourbakhsh B, Cullimore M, Zhang GX and Rostami A. IL-9 is important for T-cell activation and differentiation in autoimmune inflammation of the central nervous system. European journal of immunology. 2011; 41:2197-2206.

25. Weber F and Rieckmann P. Pathogenesis and therapy of multiple sclerosis. The role of cytokines [Article in German]. Der Nervenarzt. 1995; 66:150-155.

26. Kennedy MK, Torrance DS, Picha KS and Mohler KM. Analysis of cytokine mRNA expression in the central nervous system of mice with experimental autoimmune encephalomyelitis reveals that IL-10 mRNA expression correlates with recovery. Journal of immunology. 1992; 149:2496-2505.

27. Matsui M, Weaver J, Proudfoot AE, Wujek JR, Wei T, Richer E, Trapp BD, Rao A and Ransohoff RM. Treatment of experimental autoimmune encephalomyelitis with the chemokine receptor antagonist Met-RANTES. Journal of neuroimmunology. 2002; 128(1-2):16-22.

28. Rottman JB, Slavin AJ, Silva R, Weiner HL, Gerard CG and Hancock WW. Leukocyte recruitment during onset of experimental allergic encephalomyelitis is CCR1 
dependent. European journal of immunology. 2000; 30:2372-2377.

29. Fife BT, Huffnagle GB, Kuziel WA and Karpus WJ. $\mathrm{CC}$ chemokine receptor 2 is critical for induction of experimental autoimmune encephalomyelitis. The Journal of experimental medicine. 2000; 192:899-905.

30. Liu L, Darnall L, Hu T, Choi K, Lane TE and Ransohoff RM. Myelin repair is accelerated by inactivating CXCR2 on nonhematopoietic cells. The Journal of neuroscience. 2010; 30:9074-9083.

31. Kuwabara T, Ishikawa F, Yasuda T, Aritomi K, Nakano H, Tanaka Y, Okada Y, Lipp M and Kakiuchi T. CCR7 ligands are required for development of experimental autoimmune encephalomyelitis through generating IL-23-dependent Th17 cells. Journal of immunology. 2009; 183:2513-2521.

32. Sporici R and Issekutz TB. CXCR3 blockade inhibits T-cell migration into the CNS during EAE and prevents development of adoptively transferred, but not actively induced, disease. European journal of immunology. 2010; 40:2751-2761.

33. Villares R, Cadenas V, Lozano M, Almonacid L, Zaballos A, Martinez AC and Varona R. CCR6 regulates EAE pathogenesis by controlling regulatory CD4+ T-cell recruitment to target tissues. European journal of immunology. 2009; 39:1671-1681.

34. Godessart N and Kunkel SL. Chemokines in autoimmune disease. Current Opinion in Immunology. 2001; 13:670675.

35. Kunkel SL and Godessart N. Chemokines in autoimmunity: from pathology to therapeutics. Autoimmunity Reviews. 2002; 1:313-320.

36. Boiardi L, Macchioni P, Meliconi R, Pulsatelli L, Facchini A and Salvarani C. Relationship between serum RANTES levels and radiological progression in rheumatoid arthritis patients treated with methotrexate. Clinical and experimental rheumatology. 1999; 17:419-425.

37. Patel DD, Zachariah JP, Whichard LP. CXCR3 and CCR5 ligands in rheumatoid arthritis synovium. Clinical Immunology 2001, 98:39-45.

38. Al-Saleh $\mathrm{J}$ and el-Eissawy $\mathrm{S}$. The role of $\mathrm{T}$ helper cell subsets in pathogenesis of Systemic Lupus Erythematosus and their relation to disease activity. The Egyptian journal of immunology. 2006; 13:41-48.

39. Tran EH, Kuziel WA and Owens T. Induction of experimental autoimmune encephalomyelitis in C57BL/6 mice deficient in either the chemokine macrophage inflammatory protein-1alpha or its CCR5 receptor. European journal of immunology. 2000; 30:1410-1415.

40. Zheng HM, Jiang Y, Wang JR, Gong XL and Guo BY. Mimic peptides bonding specifically with the first and second extracellular loops of the $\mathrm{CC}$ chemokine receptor 5 derived from a phage display peptide library are potent inhibitors of experimental autoimmune encephalomyelitis. Inflammation research. 2011; 60:759-767.
41. Trebst $\mathrm{C}$ and Ransohoff RM. Investigating chemokines and chemokine receptors in patients with multiple sclerosis: opportunities and challenges. Archives of neurology. 2001; 58:1975-1980.

42. Probert L, Akassoglou K, Pasparakis M, Kontogeorgos G and Kollias G. Spontaneous inflammatory demyelinating disease in transgenic mice showing central nervous system-specific expression of tumor necrosis factor alpha. Proceedings of the National Academy of Sciences of the United States of America. 1995; 92:11294-11298.

43. Balashov KE, Rottman JB, Weiner HL and Hancock WW. CCR5(+) and CXCR3(+) T cells are increased in multiple sclerosis and their ligands MIP-1alpha and IP-10 are expressed in demyelinating brain lesions. Proceedings of the National Academy of Sciences of the United States of America. 1999; 96:6873-6878.

44. Martin D and Near SL. Protective effect of the interleukin-1 receptor antagonist (IL-1ra) on experimental allergic encephalomyelitis in rats. Journal of neuroimmunology. 1995; 61:241-245.

45. Badovinac V, Mostarica-Stojkovic M, Dinarello CA and Stosic-Grujicic S. Interleukin-1 receptor antagonist suppresses experimental autoimmune encephalomyelitis (EAE) in rats by influencing the activation and proliferation of encephalitogenic cells. Journal of neuroimmunology. 1998; 85:87-95.

46. Schiffenbauer J, Streit WJ, Butfiloski E, LaBow M, Edwards C, 3rd and Moldawer LL. The induction of EAE is only partially dependent on TNF receptor signaling but requires the IL-1 type I receptor. Clinical immunology (Orlando, Fla). 2000; 95:117-123.

47. Mahad DJ and Ransohoff RM. The role of MCP-1 (CCL2) and CCR2 in multiple sclerosis and experimental autoimmune encephalomyelitis (EAE). Seminars in immunology. 2003; 15:23-32.

48. Glabinski AR, Tani M, Strieter RM, Tuohy VK and Ransohoff RM. Synchronous synthesis of alpha- and betachemokines by cells of diverse lineage in the central nervous system of mice with relapses of chronic experimental autoimmune encephalomyelitis. The American journal of pathology. 1997; 150:617-630.

49. McManus C, Berman JW, Brett FM, Staunton H, Farrell M and Brosnan CF. MCP-1, MCP-2 and MCP-3 expression in multiple sclerosis lesions: an immunohistochemical and in situ hybridization study. Journal of neuroimmunology. 1998; 86:20-29.

50. Simpson JE, Newcombe J, Cuzner ML and Woodroofe MN. Expression of monocyte chemoattractant protein-1 and other beta-chemokines by resident glia and inflammatory cells in multiple sclerosis lesions. Journal of neuroimmunology. 1998; 84:238-249.

51. Schuette-Nuetgen K, Strecker JK, Minnerup J, Ringelstein EB and Schilling M. MCP-1/CCR-2-double-deficiency severely impairs the migration of hematogenous inflammatory cells following transient cerebral ischemia in 
mice. Experimental neurology. 2012; 233:849-858.

52. Ajami B, Bennett JL, Krieger C, McNagny KM and Rossi FM. Infiltrating monocytes trigger EAE progression, but do not contribute to the resident microglia pool. Nature neuroscience. 2011; 14:1142-1149.

53. Weiner HL. A shift from adaptive to innate immunity: a potential mechanism of disease progression in multiple sclerosis. Journal of neurology. 2008; 255 Suppl 1:3-11.

54. Severson C and Hafler DA. T-cells in multiple sclerosis. Results and problems in cell differentiation. 2010; 51:7598.

55. Hemmer B, Archelos JJ and Hartung HP. New concepts in the immunopathogenesis of multiple sclerosis. Nature reviews Neuroscience. 2002; 3:291-301.

56. Vanderlugt $\mathrm{CL}$ and Miller SD. Epitope spreading in immune-mediated diseases: implications for immunotherapy. Nature reviews Immunology. 2002; 2:8595.

57. Murphy KM and Reiner SL. The lineage decisions of helper T cells. Nature reviews Immunology. 2002; 2:933-944.

58. Ledeen RW and Chakraborty G. Cytokines, signal transduction, and inflammatory demyelination: review and hypothesis. Neurochemical research. 1998; 23:277-289.

59. Hellings N, Baree M, Verhoeven C, D’Hooghe M B, Medaer R, Bernard CC, Raus J and Stinissen P. T-cell reactivity to multiple myelin antigens in multiple sclerosis patients and healthy controls. Journal of neuroscience research. 2001; 63:290-302.

60. Lovett-Racke AE, Trotter JL, Lauber J, Perrin PJ, June CH and Racke MK. Decreased dependence of myelin basic protein-reactive $\mathrm{T}$ cells on CD28-mediated costimulation in multiple sclerosis patients. A marker of activated $/ \mathrm{memory} \mathrm{T}$ cells. The Journal of clinical investigation. 1998; 101:725730 .

61. Jacobsen M, Cepok S, Quak E, Happel M, Gaber R, Ziegler A, Schock S, Oertel WH, Sommer N and Hemmer B. Oligoclonal expansion of memory CD8+ T cells in cerebrospinal fluid from multiple sclerosis patients. Brain. 2002; 125(Pt 3):538-550.

62. Sorensen TL, Tani M, Jensen J, Pierce V, Lucchinetti C, Folcik VA, Qin S, Rottman J, Sellebjerg F, Strieter RM, Frederiksen JL and Ransohoff RM. Expression of specific chemokines and chemokine receptors in the central nervous system of multiple sclerosis patients. The Journal of clinical investigation. 1999; 103:807-815.

63. Simpson J, Rezaie P, Newcombe J, Cuzner ML, Male D and Woodroofe MN. Expression of the beta-chemokine receptors CCR2, CCR3 and CCR5 in multiple sclerosis central nervous system tissue. Journal of neuroimmunology. 2000; 108(1-2):192-200.

64. Glass WG, Liu MT, Kuziel WA and Lane TE. Reduced macrophage infiltration and demyelination in mice lacking the chemokine receptor CCR5 following infection with a neurotropic coronavirus. Virology. 2001; 288:8-17.
65. Abe C, Tanaka S, Nishimura M, Ihara F, Xuan X and Nishikawa Y. Role of the chemokine receptor CCR5dependent host defense system in Neospora caninum infections. Parasites \& vectors. 2015; 8:5.

66. Desmetz C, Lin YL, Mettling C, Portales P, Noel D, Clot J, Jorgensen $\mathrm{C}$ and Corbeau P. Cell surface CCR5 density determines the intensity of $\mathrm{T}$ cell migration towards rheumatoid arthritis synoviocytes. Clinical immunology. 2007; 123:148-154.

67. Mohan K and Issekutz TB. Blockade of chemokine receptor CXCR3 inhibits $\mathrm{T}$ cell recruitment to inflamed joints and decreases the severity of adjuvant arthritis. Journal of immunology. 2007; 179:8463-8469.

68. Azad N, LaPaglia N, Kirsteins L, Uddin S, Steiner J, Williams DW, Lawrence AM and Emanuele NV. Jurkat cell proliferative activity is increased by luteinizing hormonereleasing hormone. The Journal of endocrinology. 1997; 153:241-249.

69. Ando Y, Yasuoka C, Mishima T, Ikematsu T, Uede T, Matsunaga $\mathrm{T}$ and Inobe M. Concanavalin A-mediated T cell proliferation is regulated by herpes virus entry mediator costimulatory molecule. In vitro cellular \& developmental biology Animal. 2014; 50:313-320.

70. Redwine LS, Pert CB, Rone JD, Nixon R, Vance M, Sandler B, Lumpkin MD, Dieter DJ and Ruff MR. Peptide T blocks GP120/CCR5 chemokine receptor-mediated chemotaxis. Clinical immunology. 1999; 93:124-131.

71. Feldmeyer L, Werner S, French LE and Beer HD. Interleukin-1, inflammasomes and the skin. European journal of cell biology. 2010; 89:638-644.

72. Dinarello CA. Immunological and inflammatory functions of the interleukin-1 family. Annual review of immunology. 2009; 27:519-550.

73. Takahashi M, Galligan C, Tessarollo L and Yoshimura T. Monocyte chemoattractant protein-1 (MCP-1), not MCP-3, is the primary chemokine required for monocyte recruitment in mouse peritonitis induced with thioglycollate or zymosan A. Journal of immunology. 2009; 183:34633471.

74. Stromnes IM and Goverman JM. Active induction of experimental allergic encephalomyelitis. Nature protocols. 2006; 1:1810-1819.

75. Kafami L, Etesami I, Felfeli M, Enayati N, Ghiaghi R, Aminian A and Dehpour A. Methadone diminishes neuroinflammation and disease severity in EAE through modulating $\mathrm{T}$ cell function. Journal of neuroimmunology. 2013; 255(1-2):39-44.

76. Aminian A, Noorbakhsh F, Ghazi-Khansari M, Kafami L, Javadi S, Hassanzadeh G, Rahimian R, Dehpour AR and Mehr SE. Tropisetron diminishes demyelination and disease severity in an animal model of multiple sclerosis. Neuroscience. 2013; 248:299-306. 